BULLETIN Bulletin hispanique

HISPANIQUE Université Michel de Montaigne Bordeaux

$111-2 \mid 2009$

Varia

\title{
Del concepto de decoro a la «teoría de los estilos»
}

consideraciones sobre la formación de un tópico clásico y su pervivencia en la literatura española del Siglo de Oro

David Mañero Lozano

\section{CpenEdition}

1 Journals

Edición electrónica

URL: http://journals.openedition.org/bulletinhispanique/993

DOI: 10.4000/bulletinhispanique.993

ISSN: 1775-3821

Editor

Presses universitaires de Bordeaux

Edición impresa

Fecha de publicación: 1 diciembre 2009

Paginación: 357-385

ISBN: 978-2-86781-617-8

ISSN: 0007-4640

Referencia electrónica

David Mañero Lozano, «Del concepto de decoro a la «teoría de los estilos» », Bulletin hispanique [En línea], 111-2 | 2009, Publicado el 01 diciembre 2012, consultado el 01 mayo 2019. URL : http:// journals.openedition.org/bulletinhispanique/993; DOI : 10.4000/bulletinhispanique.993 


\title{
Del concepto de decoro a la «teoría de los estilos»: consideraciones sobre la formación de un tópico clásico y su pervivencia en la literatura española del Siglo de Oro*
}

\author{
David Mañero Lozano \\ Universidad de Jaén - Espagne
}

L'objet de ce travail est d'étudier l'évolution du concept de decorum et sa systématisation à travers les "théories du style» du point de vue de la poétique, de la rhétorique et de l'exégèse littéraire. À cette fin, nous analysons d'abord les différentes formulations théoriques sur le style élaborées par les grecs, en prêtant une attention particulière à l'école péripatéticienne. Nous nous intéressons ensuite aux auteurs latins de traités de rhétorique et de poétique, ainsi qu'à la réception des auteurs classiques durant la latinité tardive et le Moyen Âge. Nous étudions enfin la survivance des idées classiques sur le style chez les théoriciens et les auteurs d'auvres littéraires du Siècle d'Or espagnol, ce qui constitue la part essentielle de notre travail. Nous examinons en particulier le cas $d u$ roman picaresque qui, en séloignant des conventions associées au decorum, confere à ce genre une originalité sans précédent dans la prose de fiction occidentale.

* Agradecemos los comentarios y aportaciones a este trabajo realizados por David Álvarez Roblin, Antonio Carreira, Antonio Cascón Dorado, Carmen Conti Jiménez, y Santiago Fabregat Barrios. Este estudio ha contado también con una ayuda económica de la Consejería de Innovación, Ciencia y Empresa de la Junta de Andalucía, que nos permitió realizar una estancia de investigación durante el verano de 2007 en el Instituto de Investigaciones Filológicas de la Universidad Nacional Autónoma de México. Hemos de agradecer, en concreto, la atención prestada en esta institución por el Seminario de Poética, coordinado por la profesora María Cristina Azuela Bernal.

$B H i$, Tome 111, n $^{\circ} 2$ - décembre 2009 - p. 357 à 385. 
Este trabajo se propone estudiar la evolución del concepto de decoro y su sistematización a través de las "teorías del estilo" desde la óptica de la poética, la retórica y la exégesis literaria. Con este fin, analizamos en primer lugar las distintas formulaciones teóricas sobre el estilo surgidas entre los griegos, con especial atención a la escuela peripatética. Nos detenemos seguidamente en los tratadistas de retórica y poética latinos, asi como en la recepción de los autores clásicos durante la latinidad tardía y la Edad Media. Finalmente, como parte fundamental de nuestro estudio, examinamos la pervivencia de las ideas clásicas sobre el estilo en los tratadistas y autores literarios del Siglo de Oro español. En particular, nos centramos en el caso de la novela picaresca, cuya ruptura de las convenciones asociadas al decoro dota a este género de una originalidad literaria sin precedentes en la narrativa occidental.

This paper studies the evolution of the concept of 'decorum' and its systematization through the different theories of style that were developed in poetics, rhetoric and literary exegesis. Firstly, we will analyze the different theoretical formulations of style that were elaborated in Greece, with special attention to the Peripatetic school. Secondly, we will study how Latin authors of poetics and rhetoric treatises viewed this topic, as well as how Classic authors interpreted it during the Silver Age Latinity and the Middle Ages. We will examine, as a major novelty, the way in which these ideas survived among the theoreticians and literary authors during the Spanish Golden Age. In particular, we will focus on the picaresque novel, to which genre a distance from the conventions associated with 'decorum' gave its unprecedented literary originality within the Western fiction narratives.

Mots-clés: Decorum - Théories du style - Poétique - Rhétorique - Roman picaresque.

$\mathrm{E}$ L CONCEPTO de decoro y su intrínseca relación con la denominada «teoría de los estilos" no ha sido objeto de un estudio de conjunto en el que se aborde su evolución desde la antigüedad grecolatina hasta la época moderna y se consideren los distintos planteamientos surgidos desde la óptica de la poética, la retórica, la exégesis y los propios textos literarios. Sí contamos, en cambio, con algunos valiosos y ocasionalmente amplios acercamientos específicos a distintas épocas, disciplinas teóricas o autores literarios. Por esbozar en unas líneas (deliberadamente restrictivas) el estado de la cuestión, podríamos mencionar el temprano trabajo de Faral sobre Les Arts poétiques de los siglos XII al XIII ${ }^{1}$; las reflexiones salpicadas en los ensayos de Auerbach sobre el estilo de los textos bíblicos y su influencia en los autores cristianos,

1. Cf. Edmond Faral, Les Arts poétiques du XII et du XIII siècle. Recherches et documents sur la technique littéraire du Moyen Âge, Paris, Librairie ancienne Honoré Champion, 1924. 
con observaciones que alcanzan hasta la época la moderna ${ }^{2}$; los comentarios de Curtius acerca de «El sistema de los estilos en la Edad Media» ${ }^{3}$; el repaso de López Estrada de «La teoría de los tres estilos, establecida en la poética medieval» ${ }^{4}$; las publicaciones de Lida de Malkiel sobre La Celestina ${ }^{5}$; las páginas dedicadas por el hispanista Riley a "El estilo y el decoro», insertas en su espléndido estudio sobre la teoría de la novela en Cervantes ${ }^{6}$; los estudios de Kennedy sobre las teorías del estilo en Grecia y las funciones de la retórica en el mundo latino ${ }^{7}$; los apuntes de Pérez Priego sobre las conexiones entre Dante y Juan de Mena ${ }^{8}$; el exhaustivo artículo de Chevalier en torno al sentido del decoro y su práctica en la literatura española del Siglo de Oro ${ }^{9}$; y la aproximación de López Grigera a las «Teorías del estilo en el Siglo de Oro» ${ }^{10}$. Hay, además, otras referencias, agrupadas algunas en volúmenes colectivos

2. Cf. Erich Auerbach, Mimesis, Dargestelle Wirklichkeit in der Abendländischen Literatur (1942), traducción de I. Villanueva y E. Ímaz, Mimesis. La representación de la realidad en la literatura occidental (1950), México, Fondo de Cultura Económica (Lengua y estudios

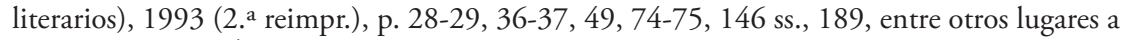
los que remite el «Índice de nombres y materias», s. u. Estilo.

3. Cf. Ernst Robert Curtius, Literatura europea y Edad Media latina, trad. Margit Frenk Alatorre y Antonio Alatorre, 2 vols., México, Fondo de Cultura Económica (Lengua y Estudios Literarios), 1955 (5. a reimpr. 1995), vol. I, p. 217-224.

4. Cf. Francisco López-Estrada, en Introducción a la literatura medieval española (1952), Madrid, Gredos (Biblioteca Románica Hispánica. Manuales, 4), 1987 (5. a ed.; 1. ${ }^{a}$ reimpr.), p. 184-189.

5. Cf. María Rosa Lida de Malkiel, La originalidad artística de «La Celestina», Buenos Aires, Editorial Universitaria, 1962; en particular, su erudita n. 2 en p. 727-728 de su «Conclusión»; obra completada póstumamente con «El ambiente concreto en La Celestina», en Estudios dedicados a J. H. Herriott, Universidad de Wisconsin, 1966, p. 145-64.

6. Cf. Edward C. Riley, Cervantes's Theory of the Novel, Oxford, Oxford University Press, 1962; trad. esp. Carlos Sahagún, Teoría de la novela en Cervantes, Madrid, Taurus (Persiles, 31), 1971, p. 209-230.

7. Cf. George Kennedy, The Art of Persuasion in Greece, Princeton, University Press, 1963; The Art of Rhetoric in the Roman World 300 B.C.-A.D. 300, Princeton, University Press, 1972. Posteriormente, Kennedy editó un panorama sobre las teorías del estilo en la antigüedad: The Cambridge History of Ancient Literary Criticism, Cambridge, Cambridge University Press, 1989; en concreto, en el primer volumen: Classical Criticism, p. 193-194, 196-197, 228, 238, 290-291, 293, 297, 301, 315, 323 у 342.

8. Cf. Miguel Ángel Pérez-Priego, «De Dante a Juan de Mena: sobre el género literario de 'Comedia'”, 1616: Anuario de la Sociedad Española de Literatura General y Comparada, I (1978), p. 151-158.

9. Cf. Maxime Chevalier, «Decoro y decoros», Revista de filología española, 73, Fasc. 1-2 (1993), p. 5-24.

10. Cf. Luisa López-Grigera, "Teorías del estilo en el Siglo de Oro», en La retórica en la España del Siglo de Oro. Teoría y práctica, Salamanca, Universidad (Acta Salmanticensia. Estudios Filológicos, 255), 1994, p. 95-103. 
$\mathrm{y}$ actas de congresos ${ }^{11}$, a las que deben sumarse las certeras consideraciones de Rico y de Cavillac sobre la novela picaresca en lugares dispersos de su producción científica ${ }^{12}$. Intentemos, entonces, examinar la evolución del concepto de decoro y su sistematización a través de las «teorías del estilo" aparecidas, como ya adelantábamos, tanto en el marco de la poética, como de la retórica y de la exégesis literaria, a fin de precisar la trayectoria de estas ideas literarias desde una perspectiva global.

\section{LA CUESTIÓN ENTRE LOS GRIEGOS}

La «teoría de los estilos», surgida en el afán por reglamentar las convenciones relativas al decoro ${ }^{13}$, encontró sus primeras formulaciones en el seno de los peripatéticos, si bien cabe destacar como antecedente las

11. Cf. Muestra de esto, son las siguientes aportaciones circunscritas al ámbito hispánico: José María Maestre-Maestre, Joaquín Pascual-Barea y Luis Charlo-Brea, ed. Humanismo y pervivencia del mundo clásico, Homenaje al profesor Luis Gil, 3 vols., Cádiz, Excmo. Ayuntamiento de Alcañiz / Departamento de Educación y Cultura del Gobierno de Aragón / Instituto de Estudios Turolenses (C.S.I.C.) / Servicio de Publicaciones de la Universidad de Cádiz, 1997; A. López-Eire, J. M. Labiano-Illundain y A. M. Seoane-Pardo, Retórica, política e ideología. Desde la antigüedad hasta nuestros días, Actas del II Congreso internacional (Salamanca, noviembre 1997), 2 vols., Salamanca, Logo, 1998; Elena Artaza, J. Durán, Carmen Isasi-Martínez, J. Lawand, María Victoria Pineda-González y Fernando Plata, coord. Estudios de filología y retórica en homenaje a Luisa López Grigera, Bilbao, Universidad de Deusto, 2000; Antonio Alvar-Ezquerra y Francisco García-Jurado, ed. Actas del X Congreso Español de Estudios Clásicos (21-25 de septiembre de 1999), Madrid, Sociedad de Estudios Clásicos, 2001; Consolación Baranda-Leturio y Ana Vian-Herrero, eds. El personaje literario y su lengua en el siglo XVI, Madrid, Instituto Universitario Menéndez Pidal / Editorial Complutense, 2006; etc.

12. Cf. Francisco Rico, La novela picaresca y el punto de vista (1970), nueva edición corregida y aumentada, Barcelona, Seix Barral (Los Tres Mundos. Ensayo), 2000, p. 16 (n. 2), 38 (n. 34), 95 y 148-9; y, sobre el Guzmán de Alfarache, Michel Cavillac, "Mateo Alemán y la "literatura", Les origines de la critique littéraire en Espagne (XVI'-XVIII" siècle), Bulletin Hispanique, 102, 2 (2000), p. 381-409.

13. Según sabemos, el concepto de decoro (designado mediante los términos griegos to prépon, to oikeion o prosêkon y los latinos decorum, accommodatum, decens, proprium o aptum) puede referirse al ámbito moral 'lo moralmente apropiado', literario 'la adecuación de las acciones, palabras, etc., a la caracterización de los personajes' o retórico 'la concordancia de elementos que conforman el discurso' (cf. Emilio del Río-Sanz, «Quintiliano y su idea del decorum: estilo, ética y retórica», Berceo, 143 (2002), p. 11-20; ejemplar dedicado a La retórica, coord. por Jorge Fernández-López; en particular, apartado «III. El decorum», p. 14-17, con especial atención al desarrollo retórico del concepto). Sobre los significados atribuidos al término decoro y su reflejo literario en el Siglo de Oro espańol, remitimos al documentado estudio de M. Chevalier, «Decoro y decoros». 
aportaciones de los sofistas, en especial de Gorgias y de sus discípulos Polo y Antístenes, a quienes se atribuye la redacción de sendos tratados sobre el estilo no conservados. Fuera del ámbito teórico, asimismo, resulta factible constatar con anterioridad -remontémonos a Homero ${ }^{14}-$ la exigencia de un estilo literario adecuado, según los requisitos del decoro, a los posibles tipos de personajes. En las páginas de Aristófanes, por citar otro ejemplo, menudean las observaciones sobre la propiedad del estilo empleado, como en el siguiente fragmento de Las ranas:

[...] para sentencias y pensamientos grandes es preciso crear palabras equivalentes. Y, además, es natural que los semidioses usen expresiones más elevadas, pues también usan vestidos mucho más ostentosos que los nuestros ${ }^{15}$.

Como punto de partida en la reflexión teórica, Aristóteles había definido los distintos géneros literarios en función de la condición moral de los personajes, de lo que se deducía el empleo de un lenguaje ajustado a su naturaleza y circunstancias. Así pues, la comedia es definida como «imitación de hombres inferiores» y la tragedia como «imitación de una acción esforzada y completa, de cierta amplitud, en lenguaje sazonado [...]» ${ }^{16}$; es decir -en interpretación de Alsina Clota- «por medio de un lenguaje enriquecido con todos los recursos ornamentales $[\ldots]{ }^{17}$.

14. Cf. George Maximilian Anthony Grube, The Greek and Roman Critics (1965), Indianapolis / Cambridge, Hackett Publishing Company, 1995, p. 4: «Homer also knows, in practice if not in theory, a number of different styles of oratory. We have the very different speeches of Odysseus, Phoenix and Ajax in the ninth book of the Iliad as well as countless other examples. We also have the clear contrast between the plain and the abundant styles, as they were to be called later, in the description given by Antenor of the earlier visit to Troy of Odysseus and Menelaus»; y, entre otros estudios de Antonio López Eire, Sobre el carácter retórico del lenguaje y de cómo los antiguos griegos los descubrieron, México, Universidad Nacional Autónoma de México, 2005; en particular, los apartados «19. Aquiles y Odiseo: dos caracteres y dos tipos de discurso» (p. 29-31) y «22. La estrategia del estilo del lenguaje» (p. 35-37).

15. Cf. Aristófanes, Ranas, introducción, comentario y traducción por José García-López, Murcia, Universidad de Murcia, 1993, p. 260.

16. Cf. Aristóteles, Poética, $1449^{\mathrm{a}}$ y $1449^{\mathrm{b}}$, edición trilingüe por Valentín García-Yebra,

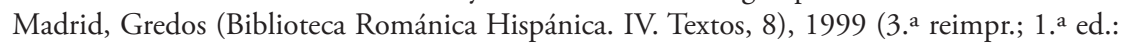
1974), p. 141 y 145.

17. Cf. Aristóteles, Poética, texto, noticia preliminar, traducción y notas de José AlsinaClota, Barcelona, Bosch (Icaria literaria), 1987, p. 29. Vid. al respecto el detallado estudio de Antonio López-Eire, «La léxis de la tragedia según la Poética de Aristóteles», Helmantica: Revista de filología clásica y hebrea, 44, no 133-135 (1993), p. 91-131; en especial, p. 103-6. 
Párrafos atrás, el autor diferenciaba las artes por los objetos imitados, lo que supone, con las prevenciones aducidas en la nota al texto, la distinción de tres modelos de caracteres imitables:

[...] puesto que los que imitan imitan a hombres que actúan, y éstos necesariamente serán esforzados o de baja calidad [...], o bien los hacen mejores que solemos ser nosotros, o bien peores o incluso iguales $^{18}$.

Por otro lado, al abordar la evolución histórica de la tragedia, el Estagirita establece una asociación directa entre el tipo de personajes y la elocución ${ }^{19}$.

En consecuencia con la mencionada concepción tripartita de los sujetos imitables, en el «Examen de las virtudes éticas» contenido en la Ética nicomáquea, IV, 8, contamos con una descripción trimembre de caracteres diferenciados por la elocución:

[...] los que se exceden en provocar la risa son considerados bufones o vulgares, pues procuran por todos los medios hacer reír y tienden más a provocar la risa, que a decir cosas agradables o a no molestar al que es objeto de sus burlas. Por el contrario, los que no dicen nada que pueda provocar la risa y se molestan contra los que lo consiguen, parecen rudos y ásperos. A los que divierten a los otros decorosamente se les llama ingeniosos, es decir, ágiles de mente, pues tales movimientos se consideran notas de carácter, y lo mismo que juzgamos a los cuerpos por sus movimientos, lo hacemos también con el carácter ${ }^{20}$.

18. Cf. Aristóteles, Poética, 1448a, ed. García-Yebra, p. 131; y p. 249, n. 36, con advertencias sobre las intervenciones en el texto de la Poética por parte de Else, quien suprime, argumentando su procedencia espuria, las referencias a una clase intermedia de sujetos imitados (cf. Aristotle, Poetics, Translated, with an Introduction and Notes by G. F. Else, Michigan, Ann Arbor, 1967). Por lo demás, en ns. 33 y 34 se apuntan los paralelismos del fragmento citado con Platón, República, X, 603c2-5. Recordemos el pasaje en cuestión: «[...] la poesía imitativa imita, digamos, a hombres que llevan a cabo acciones voluntarias o forzadas, y que, a consecuencia de este actuar, se creen felices o desdichados; y que en todos estos casos se lamentan o se regocijan» (Platón, República, en Diálogos, $I V$, intr., trad. y ns. de Conrado Eggers-Lan, Madrid, Gredos [Biblioteca Básica, 27], 2000, p. 476). Sobre la plasmación de las teorías estilísticas en la práctica literaria platónica, remitimos a Holger Thesleff, Studies in the Styles of Plato, Helsinki, Societas Philosophica Fennica, 1967.

19. Cf. Aristóteles, Poética, 1449 a , ed. Alsina-Clota, p. 26: «Sófocles aumentó el número de actores a tres, e introdujo la escenografía. Aparte de esto, se dignificó en extensión, abandonó los argumentos breves y la dicción burlesca que hasta entonces había tenido en razón de haber nacido de los coros de sátiros, y adquirió más tarde una mayor majestad».

20. Cf. Julio Pallí-Bonet, trad. y ns. de Aristóteles, Ética Nicomáquea, con intr. de 
Detengámonos, por último, en el Perì léxeōs, tratado sobre la expresión y la composición de los discursos añadido a la Retórica con posterioridad a los dos primeros libros ${ }^{21}$. En términos generales, Aristóteles formula en el Peri léxeōs la conveniencia de una adecuación entre el estilo empleado, por un lado, y la gravedad de la materia tratada, la intención comunicativa y las características socioculturales que definen al emisor, por otro lado ${ }^{22}$. Según este planteamiento, el discurso resulta adecuado, en primer lugar, "si no se habla desmañadamente de asuntos que requieren solemnidad, ni gravemente de hechos que son banales $[\ldots]{ }^{23}$; en segundo término, «si, tratándose de un ultraje, [la expresión] se muestra llena de ira; si de actos impíos vergonzosos, cargada de indignación y reverencia religiosa; si de algo que merece elogios, con admiración; y si de algo que excita la compasión, con humildad» ${ }^{24} ; \mathrm{y}$, en tercer lugar, «si se dicen las palabras apropiadas al modo de ser, se representará el talante, puesto que desde luego no suelen hablar de la misma manera el rústico y el instruido» ${ }^{25}$.

No podemos afirmar, por tanto, que Aristóteles desarrollara específicamente una teoría de los estilos, si bien la mayor parte de las aportaciones posteriores -incluida la consideración del estilo en tipos diferenciados ${ }^{26}$ - arrancan, como en tantos otros casos, de las observaciones realizadas en sus estudios sobre poética, ética y retórica, lo que no siempre ha sido debidamente valorado ${ }^{27}$.

T. Martínez-Manzano, Madrid, Gredos (Biblioteca Básica, 32), 2000, p. 126.

21. Vid. al respecto la exposición crítica de Quintín Racionero en la introducción a su traducción y anotación de Aristóteles, Retórica, Madrid, Gredos (Biblioteca Clásica, 142), 1994 (1. ${ }^{a}$ reimpr.; 1. ${ }^{a}$ ed.: 1990); en particular, las p. 78-93 dedicadas al tercer libro.

22. Sobre el concepto de adecuación, contamos también con algunas observaciones de Aristóteles en la Poética, 1454a y 1455a . Como posible antecedente de esta idea, Platón había tratado sobre la adecuación de las partes del discurso al todo: «[...] si te fijas en los pintores, arquitectos, constructores de naves y en todos los demás artesanos, cualesquiera que sean, observarás cómo cada uno coloca todo lo que coloca en un orden determinado y obliga a cada parte a que se ajuste y adapte a las otras, hasta que la obra entera resulta bien ordenada y proporcionada» (cf. Platón, Gorgias, 503 $-504^{\mathrm{a}}$, en Diálogos, trad. J. Calonge Ruiz, vol. II, Madrid, Gredos [Biblioteca Básica, 25], 2000, p. 112).

23. Cf. Aristóteles, Retórica, 1408ª, 10; ed. Q. Racionero, p. 512.

24. Ibid., 1408a, 15; p. 514.

25. Ibid., 1408a, 30; p. 515.

26. De acuerdo, pues, con los testimonios aducidos de la Poética, la Ética y la Retórica, disentimos de G. L. Hendrickson, "The Peripatetic mean of style and the three stylistic characters", The American Journal of Philology, 25, 2 (1904), p. 125-146. Vid. también, del mismo autor, "The origin and meaning of the ancient characters of style», The American Journal of Philology, 26, 3 (1905), p. 249-290.

27. A propósito de la asociación de la temática y el estilo con el rango social de los personajes, E. C. Riley, Cervantes's Theory..., denuncia la escasa atención prestada a la antigüedad clásica por parte de estudiosos como Faral: «El criterio plenamente social es un descubrimiento de la 
El análisis aristotélico de los temperamentos fue retomado por Teofrasto en los Caracteres, obra en la que el aventajado discípulo de Aristóteles describe un conjunto de treinta caracteres mediocres aquejados por defectos arquetípicos en general relacionados con el uso de la palabra (fingimiento, adulación, charlatanería, rusticidad, desvergüenza, novelería, etc. ${ }^{28}$ ), para lo cual se reproducen con frecuencia sus expresiones características ${ }^{29}$.

Teofrasto, por otra parte, fue el primer teórico en acometer un estudio sistemático del estilo, al que dedicó obras -en su mayor parte perdidascomo el Perì léxeōs, lo que tal vez explique su reconocimiento por parte de los retóricos posteriores como Cicerón o Quintiliano ${ }^{30}$. Aunque no existe acuerdo entre los estudiosos, contamos con datos que nos permiten atribuir a Teofrasto la diferenciación entre tres clases de estilos: sencillo, pleno e intermedio, según la categorización más tarde difundida a través de la retórica latina ${ }^{31}$.

Influido por los escritos peripatéticos, Demetrio propuso en el Perí Hermeneias una nueva división del estilo en cuatro categorías: el estilo llano, el elevado (también denominado elocuente), el elegante y el fuerte o vigoroso. Estos cuatro registros estilísticos, cuyo desarrollo se ha considerado falto de

Edad Media, pero Edmon Faral, que cita sólo la Rethorica ad Herennium, no llega a admitir que el germen de esta idea se halle en la Antigüedad» (p. 210, n. 1).

28. Remitimos a Elisa Ruiz-García, introducciones, traducciones y notas de Teofrasto, Caracteres, Madrid, Gredos (Biblioteca Básica, 37), 2000.

29. Sobre las fuentes que pudieron servir de inspiración en el tratado de Teofrasto, vid. R. Glenn Ussher, "Old Comedy and Character, Some Comments», Greece and Rome, 24 (1977), p. 71-79.

30. Cf. Kennedy, The Art of Persuasion..., p. 275. Como ha observado Racionero: «[...] es en la sistematización llevada a cabo por Teofrasto de algunas de las observaciones de Aristóteles sobre este asunto [la expresión artística] donde debe situarse el nacimiento de la retórica preceptista y el origen en general de la doctrina de los charaktêres o virtutes dicendi del helenismo» (cf. Introducción a Aristóteles, Retórica, p. 85).

31. Kennedy, The Art of Persuasion..., p. 278 y ss. Vid. también, entre otros, S. F. Bonner, "Dionysius of Halicarnassus and the Peripatetic Mean of Style», Classical Philology, 33 (1938), p. 257-266; y Doreen C. Innes, «Theophrastus and the Theory of Style», en Theophrastus of Eresus. On His Life and Work, ed. William W. Fortenbaugh, Pamela M. Huby y Anthony A. Long, New Brunswick, New Jersey / Oxford, Transaction Books, 1985, p. 251-267; en particular, p. 260-262. Sobre los genera dicendi, remitimos a la exposición de Heinrich Lausberg, Manual de retórica literaria. Fundamentos de una ciencia de la literatura, 3 vols. vers. esp. de J. Pérez Riesco, 4. ${ }^{a}$ reimpr.; 1. ${ }^{a}$ ed. 1966, Madrid, Gredos, 2003, vol. 2, p. 391-401. Según Richard Volkmann, Die Rhetorik der Griechen und Römer in systematischer Übersicht (Leipzig, 1885), Hildesheim, Georg Olms Verlagsbuchhandlung, 1963, p. 532, las fuentes clásicas atribuyen a Antístenes la división de los estilos en tres clases: elevado, medio y bajo; a lo que añade que esta distinción se ajusta básicamente a la retórica ática, no a la literatura en general. 
originalidad y coherencia expositiva ${ }^{32}$, son analizados y ejemplificados en relación con tres centros de interés: el asunto tratado (prágmata), la dicción (léxis) y la composición (sýnthesis). Dejada a un lado la adición de un cuarto estilo, la obra se nutre, según sabemos, de las ideas expuestas en el libro tercero de la Retórica de Aristóteles, además de recurrir en al menos cuatro ocasiones al Perì léxeōs de Teofrasto ${ }^{33}$. Por lo demás, este tratado de Demetrio constituye otra muestra del afán por sistematizar el estilo de acuerdo con las restricciones temáticas, compositivas y estilísticas impuestas por la conciencia del decoro literario. Según aclara Demetrio en II, 119-120:

[...] El escritor que rodea los hechos sin importancia de pomposidad se parece a aquel que presume de futilidades [...]

Sin embargo, algunos dicen que es necesario contar las cosas pequeñas con un lenguaje elevado y piensan que eso es prueba de un talento superior. Yo no reprocho al rétor Polícrates por elogiar a..., como si fuera Agamenón, con antítesis, metáforas y con toda clase de alabanzas, porque estaba bromeando; no lo hacía en serio y la pomposidad misma de su escrito es un juego. Como digo, se debe permitir el juego, pero se ha de cuidar lo que es conveniente para cada tema, esto es, el estilo debe ser apropiado; pequeño para lo trivial, grandioso para lo sublime ${ }^{34}$.

Como podrá observarse, las prevenciones en contra de la mezcla de estilos se convirtieron desde muy pronto en lugar común, según se ilustra, por ejemplo, en el Perí Hypsous o Tratado de lo sublime, de Longino:

[...] no se debe en un estilo sublime descender a lo vulgar y de mal gusto [...], sino que convendría usar palabras dignas de las cosas e imitar a la naturaleza, que, al formar al hombre, no colocó en nuestro rostro las partes que no se pueden nombrar $[\ldots]^{35}$.

32. Muestra de esto son los juicios de Ludovicus Radermacher, Demetrii Phalerei qui dicitur De Elocutione Libellus (Leipzig, 1901), Stutgardiae, Teubner, 1967.

33. Vid. al respecto las precisiones de José García-López en su introducción, traducción y notas de Demetrio, Sobre el estilo, Madrid, Gredos (Biblioteca Clásica, 15), 1979, p. 9, n. 3. Sobre la influencia de los peripatéticos en Demetrio, remitimos a George Maximilian Anthony Grube, A Greek Critic: Demetrius on Style, Toronto, University of Toronto Press, 1961, p. 32-39 y 56; y Kennedy, The Art of Persuasion in Greece, p. 287.

34. Cf. Demetrio, Sobre el estilo, ed. J. García-López, p. 66-67.

35. Cf. 'Longino', Sobre lo sublime, 43, ed. José García-López, Madrid, Gredos (Biblioteca Clásica, 15), 1979, p. 213. 
Como es sabido, el Perí Hypsous fue también atribuido a Dionisio de Halicarnaso, autor a quien debemos diversos opúsculos sobre el estilo, entre los que destaca el Perí Syntheseos onomaton o La composición literaria ${ }^{36}$.

Dentro del grupo de los autores griegos menores, hemos de considerar, por último, a Hermógenes de Tarso, quien planteó en el Perí ideón o Sobre las Formas de Estilo (213 y ss.), la existencia de siete modalidades estilísticas, a su vez susceptibles de presentar una serie de variantes, hasta conformar un total de veinte «ideas» $\mathrm{o}$ "formas de estilo» ${ }^{37}$.

\section{ROMA CLÁsICA}

Las repercusiones estilísticas derivadas de la materia tratada y la intención elocutiva obtuvieron una atención no menos apreciable por parte de los tratadistas de retórica latinos. Así pues, a partir de la Rhetorica ad Herennium, como también del Orator de Cicerón -aunque tal vez el primer testimonio sea el de Varrón ${ }^{38}$-, se establece la distinción entre un estilo grave, medio y leve, cuyos antecedentes -señalábamos antes- quizá se encuentren en los estudios sobre retórica de Teofrasto ${ }^{39}$. Según la Retórica a Herenio:

36. Contamos con traducción al español de Vicente Becares-Botas, Salamanca, Universidad, 1983.

37. Remitimos a las traducciones españolas de Hermógenes, Sobre los tipos de estilo y Sobre el método del tipo Fuerza, introducción, traducción castellana y notas de Antonio Sancho-Royo, Sevilla, Publicaciones de la Universidad de Sevilla (Serie Filosofía y Letras, 124), 1991; y Sobre las formas de estilo, traducción de C. Ruiz-Montero, Madrid, Gredos (Biblioteca Clásica, 184), 1993. Para un ejemplo de aplicación de las teorías de Hermógenes al análisis estilístico, vid. Antonio Sancho-Royo, «La teoría de los estilos de Hermógenes y el discurso Sobre la corona de Demóstenes», Habis, 33 (2002), p. 273-299. Mencionaremos más adelante otros ejemplos referidos a la literatura española. Por lo demás, recordemos que ya en la Retórica de Isócrates, de la que conservamos citas fragmentarias, se alude a cualidades estilísticas afines a las planteadas por Hermógenes.

38. Cf. G. M. A. Grube, The Greek and Roman..., obra citada, p. 163: «[...] there is an interesting reference in Aulius Gellius where he is discussing the three styles, which he links with three neighbouring vices; Gellius quotes Varro as saying that Pacuvius was an example of copiousness, Lucillius of simplicity, and Terence of the intermediate style [cf. Noches Aticas, 6, 14]. [...] if Gellius is quoting correctly, then Varro's was the first extant example of the use of the three-style formula, and the first, moreover, to classify authors in accordance with it».

39. Vid. supra n. 31 y su texto correspondiente. La influencia de Teofrasto sobre la teoría de los tres estilos de Cicerón es señalada por W. Kroll. Vid. Paulys Real-Encyclopädie der Classischen Altertumwissenschaft (1893-1978), Stuttgart-München, Alfred Druckenmüller Verlag, 1934, s. u. «Tullius», p. 827-1274. Sobre el origen de esta teoría, vid. Anton D. Leeman, Orationis Ratio. The Stylistic Theories and Practice of the Roman Orators, Historians and Philosophers, 2 vols., Amsterdam, Adolf M. Hakkert, 1963, vol. I, p. 29-32; y Donald A. Russell, «Theories 
Hay tres géneros, que nosotros llamamos estilos, que incluyen todos los discursos correctos. Al primero lo llamamos elevado, al segundo medio y al tercero simple. El estilo elevado consiste en una ordenación de expresiones nobles en forma fluida y abundante. El estilo medio consiste en el uso de palabras menos elevadas, pero ni demasiado bajas ni demasiado usuales. El estilo simple es el que desciende hasta el uso más corriente del lenguaje correcto ${ }^{40}$.

Recordemos, asimismo, los siguientes pasajes del Orator, obra compuesta en la madurez del autor, tras la redacción del tratado De inventione, obra a la que después se suman De oratore y Brutus:

El probar es propio de la necesidad; el deleitar, del agrado; el conmover, de la victoria, pues de todas las cualidades esta sola tiene el mayor poder para ganar las causas. Y cuantos son los deberes del orador tantos son los estilos: el sencillo en el probar, el templado en el deleitar, el vehemente en el conmover, condición ésta última que por sí sola resume toda la esencia del orador.

Es elocuente el que puede expresar con sencillez los asuntos humildes, con majestuosidad los superiores, y en estilo templado los medianos $^{41}$.

Junto a la posible influencia de Teofrasto, la teoría de los estilos, según es formulada en Cicerón, adquiere una dimensión retórica de ascendente

of Style», en Criticism in Antiquity, London, Duckworth, 1981, p. 129-147; y, en particular, el apartado 6 (p. 137-139), donde el autor se manifiesta prudente al respecto: «We should not think of the identification of the mean or middle style with sweetness or smoothness, or the accompanying illustration of Nestor, as Theophrastan; but some notion of an 'intermediate' between two recognised extremes was probably a part of his theory» (p. 138, n. 22, con indicaciones bibliográficas).

40. Cf. Retórica a Herenio, IV, 11, 8, introducción, traducción y notas de Salvador Núñez, Madrid, Gredos (Biblioteca Clásica Gredos, 244), 1997, p. 229-230.

41. Cf. M. T. Cicerón, El orador, 69 y 100-101, texto revisado y traducido por Antonio Tovar y Aurelio Bujaldón, Barcelona, Alma Mater (Colección hispánica de autores griegos y latinos), 1967, p. 28 y 40. Por lo demás, El orador trata específicamente de la teoría de los tres estilos en 20-24 y 76-112 (p. 8-10 y 31-45 de la edición citada). Asimismo, Teofrasto es tomado como referencia en el Orador, 79 a la hora de determinar las «virtudes» del estilo. Tras aludir a la «pureza» o 'corrección gramatical', la claridad expresiva y la atención al decoro, Cicerón ańade: «[...] una sola cosa faltará, la que Teofrasto enumera como cuarta entre las cualidades del estilo: el adorno grato y abundante ["Que corresponden al estilo templado y al estilo sublime”, indica n. adicional 5, p. 116]. Se pondrán sentencias agudas y frecuentes ["En compensación por la carencia de ornamentos”, reza la n. 6 subsiguiente]» (cf. M. T. Cicerón, El orador, 79, ed. A. Tovar y A. R. Bujaldón, p. 32). 
aristotélico. A este respecto, resulta sugerente la propuesta de Douglas ${ }^{42}$, quien considera como aportación original de Cicerón la asociación de las funciones asignadas por Aristóteles al orador (mouere, conciliare, docere) con los tres estilos supuestamente diferenciados por Teofrasto (sublimis, mediocris, tenuis).

En cuanto al Ars poetica de Horacio ${ }^{43}$, hemos de destacar nuevamente la influencia de los peripatéticos. En efecto, la impronta de Aristóteles y de otros tratadistas como Neoptólemo de Paros se hace patente en la propia organización temática de su famosa epístola ${ }^{44}$. En consonancia con la Poética, donde Aristóteles había recalcado la necesidad de que «sea necesario o verosímil que tal personaje hable u obre de tal modo» ${ }^{45}$, Horacio desarrolla el tópico en diversos pasajes del Ars poetica. Recordemos algunos fragmentos paradigmáticos:

Si no puedo o no sé mantener los distintos papeles y estilos de las obras, ¿por qué se me saluda como poeta? [...]

Un tema cómico no quiere ser tratado con versos trágicos [...]. Mantenga cada género el lugar que le corresponda ${ }^{46}$.

Mucha diferencia habrá si habla un rico o un héroe; un viejo maduro o alguien que hierve en plena juventud; una poderosa matrona o una diligente ama de llaves; un mercader errante o el labrador de un verde campo; uno de Cólquide o un asirio; uno nacido en Tebas y uno nacido en $\operatorname{Argos}^{47}$.

42. Vid. A. E. Douglas, "A Ciceronian contribution to rhetorical theory", Eranos, 55 (1957), p. 18-26.

43. Sobre el concepto de decoro en la Epistola a los Pisones, vid. sobre todo Charles Oscar Brink, Horace on Poetry, Cambridge, Cambridge University Press, 3 vols., 1963-1972; y Antonio García-Berrio, Formación de la Teoría Literaria Moderna. La tópica horaciana en Europa, Madrid, Cupsa, 1977; del mismo autor, Formación de la Teoría Literaria Moderna, II: Teoría poética del Siglo de Oro, Murcia, Universidad, 1980; y Antonio Camarero-Benito, "Teoría del decorum en el Ars Poetica de Horacio", Helmantica: Revista de filología clásica y hebrea, 41, $\mathrm{n}^{\circ} 124-126$ (1990), p. 247-280.

44. Vid. al respecto la presentación de Carmen M. Sanmillán-Ballesteros a su traducción de Horacio, Epistola a los Pisones, Granada, Instituto de Historia del Derecho de la Universidad de Granada (Opera historica ad iurisprudentiam exspectantia. Serie Minor II), 1973, p. VII.

45. Cf. Aristóteles, Poética, 1454a, ed. García-Yebra, p. 180-181.

46. Cf. Horacio, Epistola a los Pisones, vv. 86-92; ed. Sanmillán-Ballesteros, p. 6. Según es sabido, existe una correspondencia entre género y metro: la comedia utilizaba necesariamente el yambo; la épica, el hexámetro; la elegía, el dístico, etc.

47. Cf. ibidem, vv. 114-118; p. 7. 
[...] tienes que ir recogiendo los caracteres de cada edad y dar lo que conviene a las naturalezas y años cambiantes ${ }^{48}$.

Las teorías ciceronianas sobre las «formas convenientes» del discurso, cuyo eticismo estoico (heredero de Panecio) las diferencia de la doctrina horaciana ${ }^{49}$, fueron retomadas por Quintiliano, quien aspira, según se indica en la Institutio oratoria (XI, 5), a una mayor profundización en la materia ${ }^{50}$. La teoría de los estilos, con todo, es formulada en términos muy cercanos a los de su predecesor:

[...] parece que se pueden también distinguir entre sí verdaderas clases de estilo en el discurso. En efecto, constituyen el primer grupo aquel que llaman ischnón (sencillo), el segundo, el grande y vigoroso, que llaman hadrón (pleno), y unos autores ańaden como grupo intermedio el formado de los dos anteriores, y que otros consideran como 'el florido' (pues así lo denominan en griego, antherón). Con todo, en estas clases de estilo hay por lo general un especial fundamento: el primero parece cumplir la tarea de enseñar, el segundo la de mover, el tercero, [...] deleitar o, como dicen otros ganar la voluntad $[\ldots]^{51}$.

\section{LATINIDAD TARDÍA Y EDAD MEDIA}

Como ha sintetizado López Estrada ${ }^{52}$, las aportaciones de la retórica latina se difundieron de la mano de autores como San Agustín, quien atribuye la función de enseñar al genus submissum o tenue, la de entretener

48. Cf. ibidem, vv. 156-157; p. 9.

49. Vid. al respecto Antonio Fontán, «El análisis crítico-científico de Horacio y de Cicerón», en Humanismo romano, Barcelona, Planeta, 1974, p. 88-91.

50. El alcance retórico del concepto de decorum, sobre el que reflexiona Quintiliano al comienzo del libro XI de la Institutio oratoria, ha recibido la atención de E. del Río-Sanz, "Quintiliano y su idea del Decorum...». Vid. también la síntesis ofrecida por Marián DíezCoronado, «El decoro según la teoría retórica de Quintiliano», en A. Alvar-Ezquerra y F. García-Jurado, ed. Actas del X Congreso Español de Estudios Clásicos..., vol. 2, p. 341-346; y el ensayo de Vicente Picón, «De Cicerón a Quintiliano: retórica de los estilos y doctrina de la escritura", Edad de Oro, 19 (2000), p. 223-237.

51. Cf. Quintiliano de Calahorra, Sobre la formación del orador, XII, 10, 58-59, en Obra completa, 4 ts., ed. bilingüe, traducción y comentarios Alfonso Ortega-Carmona, Salamanca, Publicaciones Universidad Pontificia de Salamanca / Caja Duero, 2000, t. 4, p. 397-399.

52. Cf. F. López-Estrada, Introducción a la literatura..., p. 185. 
al genus temperatum y la de conmover al genus grande ${ }^{53}$; correspondencias contempladas de modo similar por San Isidoro, en el apartado «Sobre los tres tipos de elocuencia» de sus Etimologías, de más dudosa influencia ciceroniana $^{54}$.

En el plano de la exégesis literaria, hemos de resaltar la difusión alcanzada por los comentarios al estilo de Virgilio, como el de Servio ${ }^{55}$ y el de Elio Donato (seguramente compuesto con anterioridad a 363 d. C.) ${ }^{56}$, cuyos desarrollos darán lugar en la Edad Media a la conocida representación esquemática de la rota Vergilii ${ }^{57}$.

53. Sobre la influencia de Cicerón en San Agustín, vid. Maurice Testard, Saint Augustin et Cicéron, 2 vols., Paris, Études Augustiniennes, 1958. En p. 68-69 se trata sobre la influencia del Orator de Cicerón en De doctrina christiana de San Agustín.

54. Cf. San Isidoro de Sevilla, Etimologías, lib. II, cap. XVII, ed. bilingüe de José Oroz-Reta y Manuel A. Marcos-Casquero, 2 vols., Madrid, La editorial católica (Biblioteca de Autores Cristianos, 433-434), 1983, vol. I, p. 381: «[...] aunque se aborden temas trascendentales, no siempre se empleará un tono grandilocuente: será sencillo cuando enseńa; moderado cuando alaba o censura algo; grandioso cuando trata de convertir a los espíritus descarriados [...]». Según A. Fontán, San Isidoro alude al estilo humile, medium y grandiloquum «en una enumeración análoga a la de Servio y terminológicamente diversa de la de Cicerón. De modo que no parece fácil sostener la posibilidad de una directa dependencia del Orator, como insinúa Jacques Fontaine [cf. Isidore de Séville et la culture classique dans l'Espagne wisigothique, Paris, Études Augustiniennes, 1959, 2 vol., p. 283]. Por el contrario, me parece evidente que Isidoro en este lugar sigue a Servio» (cf. Humanismo romano, p. 98).

55. Según leemos en Servio: «[...] tres enim sunt characteres, humilis, medius, grandiloquus: quos omnes in hoc invenimus poeta. Nam in Aeneide grandiloquum habet, in georgicis medium, in bucolicis humilem pro qualitate negotiorum et personarum: nam personae hic rusticae sunt, simplicitate gaudentes, a quibus nihil altum debet requiri [...]» (Servii grammatici qui feruntur in Vergilii Carmina Commentarii, recensverunt Georgius Thilo et Hermannus Hagen, Lipsiae, In Aedibus B.G. Teubneri, 1887-1902; citamos por la reedición del texto en Hildesheim-Zürich-New York, Georg Olms Verlag, 1986, III, p. 1-2).

56. Cf. Giorgio Brugnoli, «Donato, Elio (Aelius Donatus)», en Enciclopedia virgiliana, Roma, Istituto della Enciclopedia Italiana (Edizione speciale per la collana "Orsa Maggiore»), 1996, II, p. 125-127; y «Vitae Vergilianae», ibid., V, p. 570-580.

57. Vid. A. Fontán, «Virgilio, los estilos y la rota vergili», en Humanismo romano, p. 94-99. Según precisa el autor en p. 96-97: «[...] para los poetas de la época de Augusto los estilos -o characteres- de la poesía eran simplemente dos (cf. Hor., Carm., I 6, 9 tenues grandia). Al primero de ellos -tenuis, gracilis- correspondían los géneros literarios horacianos, la elegía, las Bucólicas e incluso las Geórgicas virgilianas. Al segundo - grauis, fortis, seuerus, grandis- la epopeya -orte epos; grauiore sono- y la tragedia -seuera Musa tragoediae. / Pero esta doctrina poética de los dos géneros habría de sufrir [...] la interferencia con la distribución en tres de los estilos de la oratoria, estudiados en la escuela de retórica». Se trata de ideas anteriormente expuestas en "Gravis gravitas en los textos y en la conciencia romana antes de Cicerón", Emerita, XXXI (1963), p. 243-283; y «Tenvis... Mvsa? La teoría de los charakteres en la poesía augústea», Emerita, XXXII (1964), p. 193-208. Vid. la síntesis de E. R. Curtius, Literatura europea..., vol. I, p. 287, n. 36. Para un análisis del tópico, remitimos a Giorgo Stabile, bien 
La «rueda de Virgilio», documentada por vez primera hacia 1230 en la Poetria de Juan de Garlandia (ca. 1195-ca. 1272) ${ }^{58}$, se acompańa de una glosa aclaratoria (en general coincidente con las observaciones del Documentum de arte versificandi, II, 3, 145, de Geoffroi de Vinsauf), en la que se afirma la existencia de tres estilos asociados a las distintas condiciones del hombre, de manera que «[...] pastorali vitae convenit stylus humilis, agricolis mediocris, gravis gravibus personis quae praesunt pastoribus et agricolis» ${ }^{59}$.

La dimensión social del tópico, a nuestro juicio -y salvadas las distanciasdeudora del pensamiento aristotélico, adquiere un evidente protagonismo a partir de Garlandia, lo que han destacado autores como Faral o Quadlbauer ${ }^{60}$.

En cuanto a la tradición hispánica en lengua vernácula, López Estrada ha resaltado la variedad de interpretaciones de la que fue objeto la teoría de los tres estilos:

[...] hay que considerar por una parte las teorías de origen en los tratados del latín antiguo, y por otra, su interpretación en las Poéticas medievales y la adaptación en la conciencia literaria de los primeros «críticos» que observan las obras en lenguas vernáculas ${ }^{61}$.

De particular interés, por lo que afecta a estos "primeros críticos» de la literatura española, son las observaciones de Juan de Mena en el «Proemio

documentado: «rota Vergilii», en Enciclopedia virgiliana, vol. IV, p. 586-587. En cuanto a la recepción de Virgilio por parte de algunos tratadistas italianos del s. XV como Scalígero, Trissino, Minturno y Tasso, remitimos al capítulo «Virgilio en la poética quinientista: consideraciones teóricas sobre la épica y su lectura política» (p. 147-200) de la tesis doctoral de Lara Vilà i Tomàs, Épica e imperio. Imitación virgiliana y propaganda política en la épica española del siglo XVI, Universidad Autónoma de Barcelona, 2001.

58. Contamos con edición del texto a cargo de Giovanni Mari, «Poetria Magistri Johannis Anglici de Arte Prosayca Metrica et Rithmica», en Romanische Forschungen, XIII (1902), p. $883-965$.

59. Cf. J. de Garlandia, Poetria, en E. Faral, Les Arts poétiques..., p. 87. Por lo demás, remitimos a las observaciones sobre el decoro en el apartado "IV. Los ornamentos del estilo» de La poética nueva, vv. 742-ss, de Geoffroi de Vinsauf, p. 26-s en la traducción de Carolina Ponce, México, Universidad Nacional Autónoma de México (Instituto de Investigaciones Filológicas. Bitácora de Retórica, 8), 2000.

60. En palabras de Stabile: «Significativa al riguardo la variazione apportata da Giovanni di Garlandia, che traduce la triade virgiliana miles-agricola-pastor nella tipologia medievale curiales-civiles-rurales, e che subordina rigidamente alla teoria degli status el registro espressivo degli stilus» (cf. G. Stabile, «rota Vergilii», p. 586b). Son observaciones de F. Quadlbauer, Die antike Theorie der genera dicendi im lateinischen Mittelalter (Österreichische Akademie der Wissenschaften Philos.-hist. Kl. Sitzungsberichte 241, Bd. 2.), Viena, 1962.

61. Cf. F. López Estrada, Introducción a la literatura..., p. 188. 
segundo" de la Coronación del marqués de Santillana, pasaje en el que se explicita la nómina de autores que ejemplifican, al parecer de Mena, las tres modalidades literarias:

Sepan los que lo ignoran que por alguno de tres estilos escriven o escrivieron los poetas: por estilo trágico, sátiro o comedio. Tragedia es dicha la escritura que fabla de altos fechos, e por bravo e sobervio e alto estilo, la qual manera seguieron Omero, Vergilio, Lucano, Estaçio; por la tragedia escritura, puesto que comiença en altos prinçipios, su manera es acabar en tristes e desastrados fines. Sátira es segundo estilo de escrivir, la naturaleza de la qual escritura e ofiçio reprehende los vicios, del qual estilo usaron Oraçio, Persio e Juvenal. El terçero estilo es comedia, la qual tracta de cosas baxas e pequeñas, e por baxo e omilde estilo, e comiença en tristes prinçipios e fenesçe en alegres fines, del qual usó Terencio [...]. De los quales tres estilos más largamente poniendo sus derivaçiones e sinificados fabla el comentador sobre la Commedia del Dante en el cuarto preánbulo ${ }^{62}$.

Muestra, por otra parte, de la exégesis virgiliana impulsada por los comentarios de Donato dentro del ámbito hispánico son las interpretaciones alegóricas planteadas por Juan del Encina en su Translación de las "Bucólicas» de Virgilio ${ }^{63}$. Según reza el primero de los prólogos de la obra:

62. Cf. La Coronación del marqués de Santillana, en Juan de Mena, Obras completas, ed. Miguel Ángel Pérez-Priego, Barcelona, Planeta, 1989, p. 107-8. Según nota al pie del editor: «Alude en concreto al comentarista Benvenuto Rambaldi de Imola, que fue lector público de la Divina Commedia en Bolonia a finales del siglo XIV y escribió un compendioso Comentum super Dantis Alighieri Comoediam, muy difundido también en la España del siglo $\mathrm{XV}$ ». En otro lugar, Pérez Priego precisa: «Toda esa teoría sobre la comedia, refugiada en la tradición enciclopédica y poética seguramente hubiese tenido escasa eficacia operativa sobre la literatura vulgar, si no hubiese sido consagrado el término nada menos que para dar título al sublime poema de Dante. Inmerso en la herencia cultural mediolatina, Dante alude en diversos lugares de su obra a la teoría de los géneros. En el De vulgari eloquentia (II, iv) distingue tragedia y comedia en cuanto al estilo, «vulgar ilustre» en aquélla, «mediocre» y «vulgar humilde» en ésta [...]» (cf. M. Á. Pérez Priego, De Dante a Juan de Mena..., p. 154). En cuanto a la repercusión de Dante en la literatura espańola del Siglo de Oro, vid. Margherita Morreale, «Apuntes bibliográficos para el estudio del tema Dante en España hasta el siglo XVII» (Estratto dagli Annali del corso di Lingue straniere della Università di Bari, VIII, 1967). Vid. además las precisiones de A. Fontán sobre el capítulo II, 6 del De vulgari eloquentia, dedicado a la estilística (cf. Humanismo romano, p. 248-50).

63. Vid., entre otras referencias, James A. Anderson, Juan del Encina: aesthetics of his poetry, Michigan, Ann Arbor, 1985; y Alberto Blecua, «Virgilio en España en los siglos XVI y XVII», en Studia Virgiliana, Actes del VI Simposi d'Estudis Clássics, Universidad Autónoma de Barcelona, 1985, p. 61-77. 
[...] acordé dedicaros las Bucólicas de Virgilio, que es la primera de sus obras, adonde habla de pastores, siguiendo, como dize el Donato, la orden de los mortales, cuyo exercicio primeramente fue guardar ganados, manteniéndose de frutas silvestres, y después siguióse la agricultura, y andando más el tiempo nacieron batallas, y en esta manera el estilo del gran Homero mantuano en sus tres obras principales procedió, de las cuales, por agora, para entrada y preludio de mi propósito, estas Bucólicas quise trasladar, trobadas en estilo pastoril, aplicándolas a los muy loables hechos de vuestro reynar, según parece en el argumento de cada una ${ }^{64}$.

\section{EDAD DE ORO}

También al dictado de los clásicos y de otras fuentes italianas como el De vulgari eloquentia de Dante o el Discorsi dell'Arte Poetica de Tasso, los tratadistas del Siglo de Oro siguieron contemplando una teoría de los estilos basada en la tradicional separación entre géneros con distinta gravedad ${ }^{65}$. Es el caso del De tribus dicendi generibus sive de recta informandi stili ratione commentarius (Alcalá, Andrés de Angulo, 1570), de Alfonso García Matamoros, quien reelabora las aportaciones de Cicerón y Quintiliano ${ }^{66}$.

Hemos de señalar, asimismo, la pervivencia de las teorías de Hermógenes acerca de las denominadas «ideas» $\mathrm{O}$ "formas de estilo» ${ }^{67}$. Entre otros ejemplos

64. Cf. Juan del Encina, Translación de las «Bucólicas» de Virgilio, en Obras completas, 4 vols., edición, introducción y notas de Ana María Rambaldo, Madrid, Espasa-Calpe (Clásicos Castellanos, 218), 1978, vol. I, p. 218-341; la cita, en p. 219-220.

65. Vid. sobre todo José Rico-Verdú, La retórica española de los siglos XVI y XVII, Madrid, CSIC (Anejos de Revista de Literatura, 35), 1973, donde se documenta el tópico de los tres estilos en autores como García Matamoros (remitimos al apartado sobre «De tribus dicendi generibus», p. 127-134) o Andrés Sempere (p. 209-212).

66. Contamos con edición de Miguel Ángel Rábade-Navarro y María del Socorro PérezRomero, en el disco compacto Retóricas españolas del siglo XVI escritas en latín, gracias a la iniciativa coordinada por Miguel Ángel Garrido-Gallardo, Madrid, Fundación Ignacio Larramendi / Consejo Superior de Investigaciones Científicas, 2004.

67. Vid. al respecto L. López-Grigera, «Teorías del estilo en el Siglo de Oro», en La retórica en la España del Siglo de Oro..., p. 97 y ss. Según precisa la autora: «Estas ideas o formas de estilo, que seguían vigentes en el mundo bizantino, habían entrado indirectamente en la Europa occidental al promediar el primer tercio del siglo XV a través de los griegos que llegaron a Italia, especialmente a través de Jorge de Trebizonda, que incluye en su Rhetoricorum Libri V las "ideas" de Hermógenes. Con éste, como hemos visto antes, estudiaron muchos españoles en Roma, según testifica Fernando Alonso de Herrera, primer catedrático de Retórica en Alcalá, para cuyos alumnos imprimió en 1511 en $R L V$, primera edición fuera de Italia [...]» (p. 98). Vid. además Ferrán Grau-Codina, «La teoría del decoro y la última de las ideas de Hermógenes en algunas retóricas del Renacimiento», en José María Maestre- 
estudiados por López Grigera, la influencia del Peri ideón de Hermógenes es apreciable en tratados como De Imitatione, seu de formandi styli ratione (Amberes, Martín Nucio, 1554), de Sebastián Fox Morcillo ${ }^{68}$; en De oratione libri VII. Quibus non modo Hermogenes ipse totus... (Basilea, Oporino, 1558), de Antonio Lulio; en la epístola a Jorge de Trebizonda (dos de enero de 1465) de Alfonso de Palencia ${ }^{69}$; por no contar con las manifestaciones apreciables en el plano literario, como en el Lazarillo de Tormes ${ }^{70}$, o en las obras de Guevara $^{71}$, Garcilaso ${ }^{72}$, Quevedo ${ }^{73}$, Cervantes $^{74}$, etc.

Maestre, Joaquín Pascual-Barea y Luis Charlo-Brea, ed. Humanismo y pervivencia del mundo clásico, vol. 2, p. 769-778.

68. Se conserva ejemplar de este tratado en la Biblioteca Nacional (R/27976). María Victoria Pineda ha dedicado su tesis doctoral en la Universidad de Michigan a la edición, traducción y estudio de esta obra de Fox Morcillo: «Theories of Literary Imitation in Sixteenth-Century Spain. Edition and translation of Sebastian Fox Morcillo's De imitatione». Contamos con versión española: La imitación como arte literario en el siglo XVI español, Sevilla, Diputación Provincial, 1994.

69. Vid. Javier Durán-Barceló, «Una teoría sobre los estilos en una carta de Alfonso de Palencia", en Humanismo y pervivencia del mundo clásico, Actas del I Simposio sobre Humanismo y pervivencia del mundo clásico (Alcañiz, 8 al 11 de mayo de 1990); coord. por José María Maestre-Maestre, Joaquín Pascual-Barea, Cádiz, Instituto de Estudios Turolenses (C.S.I.C.) / Servicio de Publicaciones de la Universidad de Cádiz, Vol. 1, 1993, p. 415-423; donde se analiza la relación establecida por Palencia entre las «formas de estilo» expuestas por Hermógenes y el esquema galénico de las cuatro complexiones humanas.

70. Vid. Elena Artaza, El Ars narrandi en el siglo XVI español, Bilbao, Universidad de Deusto, 1988, p. 277-303. Vid. antes, de la misma autora, La "Narratio" en las retóricas españolas del siglo XVI, Tesis doctoral, Universidad de Deusto, Bilbao, 1985.

71. Vid. Luisa López-Grigera, «Los estilos de Guevara en las corrientes retóricas de su época", en Actas del Symposio sobre Fray Antonio de Guevara, Mondoñedo, septiembre de 1990; en La retórica en la España del Siglo de Oro..., p. 107-120.

72. Sobre la teoría de los estilos en las Anotaciones de Herrera a Garcilaso, vid. Luisa LópezGrigera, «La retórica griega post-aristotélica en el Siglo de Oro», en La retórica en la España del Siglo de Oro..., p. 69-83; en particular, apartado III, p. 83; María Victoria Pineda-González, "Las silabas llenas de Garcilaso: apuntes para una teoría de los estilos en las Anotaciones de Herrera», en E. Artaza, J. Durán, C. Isasi Martínez, J. Lawand, M. ${ }^{a}$ V. Pineda González y F. Plata, coord. Estudios de filología y retórica..., p. 371-386; y, de la misma autora, «El resplandor de Garcilaso: nuevos apuntes para una teoría de los estilos en las Anotaciones de Herrera", Criticón, 87-89 (2003) [Ejemplar de homenaje a Stefano Arata], p. 679-688. Junto a la influencia de Hermógenes, a quien alude Herrera en varios pasajes (cf. Fernando de Herrera, Anotaciones a la poesía de Garcilaso, ed. Inoria Pepe y José María Reyes, Madrid, Cátedra [Letras Hispánicas, 516], 2001, p. 331, 357 y 479), la preocupación por el estilo y el decoro en este autor entronca con tratadistas como Bembo, Ruscelli, Scalígero o Minturno (vid. por ejemplo p. 418, 482 y 608). Por lo demás, remitimos al comentario de I. Pepe y J. M. a Reyes sobre los conceptos de "perspicuitas», «venustas» y «puritas» en p. 58 y 59 . De especial interés es el escolio dedicado a licenciosa (p. 471-2).

73. Vid. Luisa López-Grigera, "Análisis de un soneto de Quevedo», en Dicenda, 7 (1988), 
Resulta controvertido, dicho sea de paso, hasta qué punto las ideas sobre el estilo en estos autores presentan una influencia directa de Hermógenes, o bien estarían condicionadas por las corrientes erasmistas ${ }^{75}$.

El tópico de la separación de estilos aparece también formulado en la Philosophia antigua poética (Madrid, 1596) de Alonso López Pinciano, principal difusor en Espańa de la doctrina aristotélica:

[...] la tragedia es hecha en alto estilo, y la comedia, en baxo, no es diferencia nueua, porque es anexo el estilo a la persona $\mathrm{q}[u e]$ habla: que, si en la comedia es persona común, y en la tragedia, graue, como es dicho, claro está que el désta ha de ser estilo graue, y el de aquélla, humilde; y, si es en las paliatas y togatas, también será el estilo graue, como el de la trágica por ser graues las personas destas especies de comedia $^{76}$.

Un par de décadas más tarde, en las Tablas poéticas (Murcia, 1617) de Cascales, autor en el que advertimos una especial influencia de los tratadistas italianos ${ }^{77}$, se argumenta cómo «del concepto se engendra la variedad de estilo»:

p. 105-116; y "Cuestión de géneros y estilos en dos sonetos de Quevedo», en Symbolae Pisanae. Studi in onore di Guido Mancini, a cura di B. Perinán e F. Guazzelli, Pisa, Giardini, 1989, II, p. 335-347.

74. Vid. Luisa López-Grigera, "Introducción a una lectura retórica de Cervantes: "El Quijote" a la luz de Hermógenes», en La retórica en la España del Siglo de Oro..., p. 165178.

75. Vid. al respecto Luisa López-Grigera, «Influjo de Erasmo en las teorías de la lengua y del estilo en el siglo XVI», en La retórica en la España del Siglo de Oro..., p. 61-68; y Víctor de Lama, «Erasmo y la lengua en la Espańa renacentista», Edad de Oro, XIX (2000), p. 131153; en particular el apartado 4. El estilo literario de Erasmo como modelo de imitación, en p. $141-146$.

76. Cf. Alonso López-Pinciano, Philosophía antigua poética, ed. Alfredo Carballo-Picazo, 3 vols., Madrid, CSIC, 1973, vol. III, p. 28-9.

77. Según constata E. C. Riley, Cervantes's Theory..., p. 22: «[...] Cascales estuvo muy influido por los italianos, probablemente en mayor grado que lo estuvo El Pinciano». En relación con la posible influencia de Cascales sobre el corpus literario del que nos ocupamos, es de recordar que las Tablas poéticas no se publicaron hasta 1617 (Murcia, Luys Berós); y no contamos con una segunda edición hasta 1779 (Madrid, Antonio de Sancha). No obstante, dado que la obra se compuso hacia 1604 (cf. Justo García-Soriano, El humanista Francisco Cascales: su vida y sus obras (Estudio biográfico, bibliográfico y crítico), Madrid, Academia Española, 1924, p. 44), resulta de interés contrastar los planteamientos de Cascales con las producciones literarias de comienzos del siglo XVII, sobre todo en la medida en que las Tablas constituyen un buen índice de la absorción de las ideas procedentes de Italia en Espańa. 
Castalio. - [...] Dante Aliguiero affirmó que el estilo procedía de las palabras, las quales le hazían grave, humilde o mediano.

Pierio. - Y aun a mí me lo parece, que las palabras escogidas y la virtud de la elocución haze el estilo y le pone en el grado que quiere.

Castalio. - Oýd lo que responde a esso Torquato Tasso, gran poeta y gran maestro de la poética. Los conceptos son el fin y, por consequencia, la forma de las palabras y de las vozes [...] El concepto del épico es grave y magnífico; el concepto del lýrico es florido y ameno [...]. Ved, por exemplo, cómo tratando el épico y el lýrico unas mismas cosas, usan diversos conceptos, de la qual diversidad de conceptos mana después la diversidad del estilo ${ }^{78}$.

De este modo, los sujetos de condición humilde, asociados al estilo de la comedia, tenían vedado el empleo de todo concepto "grave y magnífico». De nuevo en palabras de Pierio y Castalio:

Pierio. - [...] como ésta [la comedia] mira principalmente a las costumbres y es un espejo de la vida humana, usa en muchas ocasiones sentencias endereçadas a este fin. Y sé también que no a de dezir sentencias quienquiera de la comedia, sino gente de experiencia o docta. Bueno sería que a un rústico le oyéssemos consejos sacados de las entrañas de la filosofía, o discurrir largamente diziendo el cauteloso trato de la corte. De la dictión, también me parece que avéis tratado en su lugar lo que basta [...].

Castalio. - No sé qué os diga más de la dictión, sólo que el estilo más humilde y lenguage menos affectado conviene a la comedia [...] (220).

Las advertencias de Cascales -indica Riley ${ }^{79}$ - parecen encontrar eco en $E l$ pasajero de Suárez de Figueroa, quien probablemente se refiere al autor de las Tablas poéticas al recoger las opiniones de cierto "gramático» en materia literaria:

Humilde [ha de ser la comedia], cuanto a la acción, siendo los que constituyen la fábula cómica plebeyos, o, cuando mucho, ciudadanos, en que también pueden entrar soldados; por manera que si los que se introducen son gente común, forzosamente ha de ser el lenguaje familiar; mas en verso, por la suavidad con que deleita. De aquí se

78. Cf. Francisco Cascales, Tablas poéticas, ed. Benito Brancaforte, Madrid, Espasa-Calpe (Clásicos Castellanos, 207), 1975, p. 232-233 y 235.

79. Cf. E. C. Riley, Cervantes's Theory..., p. 211. 
infiere (escribe un gramático) ser error poner en la fábula hechos de principales, por no poder inducir risa, pues forzosamente ha de proceder de hombres humildes ${ }^{80}$.

La conciencia de las convenciones basadas en la separación de estilos, y en particular de las derivadas de la exégesis virgiliana, nos queda también patente en la novela pastoril, donde toda alteración del registro estilístico asociado al género se considera necesitada de justificación. Recordemos, en el que tal vez constituya el máximo distanciamiento del registro tradicional, el comienzo de la Fábula de Polifemo y Galatea gongorina, en la que, de acuerdo con el tópico, se reconoce la deuda ante una "culta sí, aunque bucólica, Talía» ${ }^{81}$. Como ha estudiado Aurora Egido, la asociación de la materia pastoril al stylus humilis entró progresivamente en contradicción con las aspiraciones del género por alcanzar un grado superior de dignidad literaria, cuando no por abordar cuestiones de mayor relevancia social o de asumir incluso una función doctrinal teológica ${ }^{82}$.

80. Cf. Cristóbal Suárez de Figueroa, El pasajero, presentación de José Manuel Blecua Teijeiro, introducción, edición, notas e índices de M. a Isabel López Bascuñana, Barcelona, Promociones y Publicaciones Universitarias (Textos universitarios, 5), 1988, p. 222. Según anota la editora en n. 25: «Lope de Vega también afirma en su Arte nuevo de hacer comedias (vr. 73) que "entremés del Rey jamás se ha visto". En cuanto a la condición plebeya de los graciosos, hay que recordar que, a pesar de la presencia de personajes aristocráticos en las obras de Aristófanes y Plauto, ya desde La Odisea la jocosidad era inspirada por la clase social baja. Cfr. A. Navarro González, Calderón de la Barca. De lo trágico a lo grotesco, ed. Universidad de Salamanca, Edition Reichenberger, 1984, esp. cap. VI, "Lo plebeyo y lo grotesco en Calderón: Céfalo y Procris”, pp. 140-170». Vid. además las opiniones de Suárez de Figueroa al comienzo del Alivio III, p. 214-216.

81. Cf. Luis de Góngora, Fábula de Polifemo y Galatea, v. 2, ed. Alexander Parker, Madrid, Cátedra (Letras Hispánicas, 171), 1993 (5. a ed.), p. 133. Vid. al respecto los ejemplos de la Arcadia de Sannazaro y la Galatea de Cervantes aportados por E. C. Riley, Cervantes's Theory..., p. 215.

82. Cf. Aurora Egido, “Sin poética hay poetas”. Sobre la teoría de la égloga en el Siglo de Oro", Criticón, 30 (1985), p. 43-77. En la línea abierta por este importante trabajo de la profesora Egido, contamos con el artículo de Jesús Gómez, «Sobre la teoría de la bucólica en el Siglo de Oro: hacia las églogas de Garcilaso", Dicenda, 10 (1991-1992), p. 111-125; continuado al año siguiente en «El desarrollo bucólico a partir de Garcilaso y la poesía pastoril (s. XVI)», Dicenda, 11 (1993), p. 171-195. Sobre las contradicciones derivadas de la oposición entre el estilo humilde de la literatura pastoril y la exigencia social de un estilo elevado dentro del sistema de valores aristocrático, vid. J. Richard Andrews, Juan del Encina: Prometheus in Search of Prestige, Berkeley and Los Angeles, University of California Press (University of California Publications in Modern Philology, 53), 1959, p. 29-32, donde se traen ejemplos referidos a Juan de Mena, el Marqués de Santillana, Íñigo de Mendoza y Juan del Encina. 
En efecto, en paralelo al largo proceso de sistematización de las opiniones sobre el decoro literario, a partir del cristianismo, la literatura occidental experimenta la introducción de unas ideas contrarias a la separación de estilos, lo que ha recibido especialmente la atención de Auerbach ${ }^{83}$.

Por su parte, González Maestro señala:

[...] desde la época medieval se desarrolla una literatura en la que diferentes tipos de personajes comienzan a distanciarse cada vez más de las exigencias formales y funcionales del decoro. Se trata de creaciones literarias afines a las formas narrativas y a los géneros cómicos, modalidades ambas que no se vieron involucradas en los objetivos normativos de las poéticas clásicas. En los Enxiemplos entre el conde Lucanor y Patronio, en el Decamerone de Boccaccio, en The Canterbury Tales de Chaucer, y más tarde en las formas polifónicas de la novela renacentista, así como en [...] la farsa, la comedia y lo carnavalesco, a través de las fêtes de foules francesas, los juegos del Boy-Bishop o los Folk-plays ingleses, la posterior commedia dell'arte italiana, y los pasos o entremeses del siglo XVI español, etc., encontramos ejemplos decisivos en los que el personaje literario rompe progresivamente el decorum $[\ldots]^{84}$.

Estas observaciones, en las que no vamos a detenernos ${ }^{85}$, ponen de manifiesto cómo las convenciones sobre el decoro ejercieron, según era

83. Cf. E. Auerbach, Mimesis..., p. 49, entre otros lugares: «[...] la antigua convención estilística se derrumba por sí sola, pues la actitud de las personas afectadas sólo puede ser descrita con la mayor seriedad; un pescador, un publicano, un joven rico cualquiera, una samaritana o una adúltera cualquiera son sacados de las circunstancias vulgares de su vida y puestos de pronto en presencia de Jesús, y la reacción de dichas personas en este instante reviste necesariamente una profunda solemnidad y a menudo un carácter trágico. La antigua regla estilística según la cual la imitación de la realidad, la descripción de episodios corrientes, sólo podía ser cómica (o en todo caso idílica) es, por consiguiente, incompatible con la representación de fuerzas históricas, [...] pues se ve obligada a penetrar en las profundidades de la vida cotidiana del pueblo [...]».

84. Cf. Jesús González-Maestro, «Poética clásica y preceptiva lopesca en el teatro experimental cervantino. Sobre decoro y polifonía», en El teatro en tiempos de Felipe II. Actas de las XXI Jornadas de teatro clásico, Almagro, 7, 8 y 9 de julio de 1998, ed. Felipe Blas Pedraza-Jiménez y Rafael González-Cañal, Almagro, Ediciones de la Universidad de CastillaLa Mancha, 1999, p. 65-82; en particular, p. 68-9. La práctica totalidad de este estudio, bien que con ligeras alteraciones en el orden de párrafos, se reproduce sin ningún aviso en Jesús González-Maestro, «Poética del personaje en las comedias de Miguel de Cervantes», Cervantes: Bulletin of the Cervantes Society of America, 19, nº 2 (1999), p. 55-86.

85. Sobre el estilo del Decamerón, vid. E. Auerbach, Mimesis..., p. 204-205. Por lo demás, en palabras del mismo autor: «En la literatura moderna, todo personaje, cualquiera que sea su carácter y posición social, y todo episodio, tanto fabuloso como de alta política, o limitado a lo doméstico, pueden ser tratados por el arte imitativo, y lo son la mayoría de las veces, 
esperable, una menor presión sobre aquellos géneros no estudiados por las poéticas clásicas.

La ruptura de la separación de estilos, que comienza con la difusión de los ideales del cristianismo ${ }^{86}$, se ve refrendada en el ámbito de la preceptiva literaria durante todo el Siglo de Oro ${ }^{87}$. La reflexión teórica sobre el estilo comenzaba, pues, a manifestar bastantes signos de inconsistencia, si bien, por norma general, las mencionadas infracciones del decoro poseían un mero alcance cómico, cuando no idealista (como en los libros de pastores), sin que estuvieran encuadradas en un marco literario verdaderamente problemático. Como excepción a esto, contamos con el caso de la novela picaresca, circunstancia que dota al género de una originalidad literaria sin precedentes en la narrativa occidental, de lo que tal vez podamos considerar como precursora La Celestina ${ }^{88}$.

de manera severa, problemática y trágica. En la antigüedad esto es totalmente imposible. Aunque en las poesías pastoriles y eróticas existan algunas formas intermedias, en conjunto rige la regla de la separación de estilos [...]: lo que corresponde a la realidad vulgar, a lo cotidiano, no puede ser presentado más que en la comedia, sin ahondamientos problemáticos $[\ldots]$..

86. Recordemos, dentro de la tradición hispánica, el caso paradigmático del Corbacho. Sara Mañero, «El arcipreste de Talavera» de Alonso Martínez de Toledo, Toledo, Instituto Provincial de Investigaciones y Estudios Toledanos (C.S.I.C. Diputación Provincial de Toledo), 1997, ha valorado los planteamientos críticos en torno al problema de la mezcla de estilos en esta obra. Remitimos a los apartados «Recursos de estilo» (p. 213-221) y "Apéndice I.-Apuntes de estilo» (p. 463-477); y, en particular, p. 220-221.

87. Según puntualiza Riley: «Los teóricos de los siglos XVI y XVII se vieron obligados a modelar sus preceptos, estableciendo toda clase de excepciones. Vives [cf. De causis corruptarum artium, IV], siguiendo a Quintiliano, aceptaba que el estilo debía acomodarse al tema tratado, pero decía que había tantas gradaciones de estilo posibles como gamas de color hay entre el blanco y el negro [...]. Muzio, atendiendo al modelo social, admitía descensos en la escala de los estilos, pero no subidas. El Pinciano empezaba por asociar de una manera específica los tres estilos a los tres estados sociales (patricio, mediano y plebeyo), como consecuencia inevitable de ser la poesía imitación de la vida. Pero luego recordaba que los reyes no utilizan de hecho el estilo alto en sus conversaciones [...]. Cascales se vio obligado a sugerir la utilización de recursos tales como el de limitar el desarrollo de la acción principal a la gente humilde y los episodios a la gente ilustrada, o viceversa» (cf. E. C. Riley, Cervantes's Theory..., p. 213).

88. Según M. ${ }^{a}$ Rosa Lida de Malkiel, La originalidad artística..., p. 727: «La insólita interferencia de personajes "bajos" y personajes "altos" en la acción perfila la no menos insólita autonomía artística concedida a aquéllos; quizá la faceta más singular de la atención objetiva de La Celestina a la realidad sea la detenida pintura de los personajes humildes o viles, en ocasiones contrapuestos con tácita aprobación a los nobles [...], y siempre retratados con entera compenetración. Asombran, en particular, las criaturas del hampa, representadas desde dentro, tal como ellas mismas se ven, no desde un punto de vista sobrepuesto, satírico o moralizante». 
Lazarillo de Tormes y, a imitación suya, los Guzmanes, supuso -en expresión de Geoffroi de Vinsauf- una original ruptura de la «ratio personarum»" ${ }^{89}$, cuyo marco de referencia ha sido expuesto por Rico ${ }^{90}$.

En el caso del Lazarillo, estaremos de acuerdo en considerar el empleo de un estilo desenvuelto, más o menos ajustado a la condición humilde del pícaro $^{91}$, pero lo cierto es que el discurso de Lázaro consiste, contra toda expectativa, en ese "discurrir largamente diziendo el cauteloso trato de la corte», improcedente en boca de un «rústico» según el fragmento antes citado de Cascales ${ }^{92}$.

Por lo que toca al pícaro de Mateo Alemán, la gravedad del personaje se incrementa visiblemente tanto en lo concerniente al contenido como al registro estilístico adoptado ${ }^{93}$. Desde luego, Guzmán no sólo se plantea representar -cuando no sancionar-, como hace Lázaro de Tormes, las distintas capas sociales, desde las más desfavorecidas hasta los representantes

89. Cf. E. Faral, Les Arts poétiques..., p. 87.

90. Cf. F. Rico, La novela picaresca..., p. 148: «De la Edad Media al siglo XVIII [...] la dignidad de la obra literaria solía considerarse determinada por la dignidad social de sus protagonistas, ratione personarum. La jerarquía de géneros y estilos, así, duplicaba la jerarquía de rangos de una sociedad sólidamente constituida sobre las diferencias de cuna [...]. Los personajes se concebían ya tipificados, y no cabía -por ejemplo- tratar de un sujeto humilis en un estilo gravis, reservado para las gentes de importancia [...]. En particular, los plebeyos tenían prohibida la entrada en la literatura con la plena personalidad de la vida real. Únicamente se les admitía reducidos a una faceta peyorativa, como motivo de burla o de vituperio».

91. En observación de F. Rico: «El lenguaje tampoco se sale perceptiblemente de las fronteras que cabría fijar a un sujeto sin estudios conocidos, pero más listo que el hambre y formado junto a un ciego sabidillo, un buldero dueño "de un gentil y bien cortado romance" y otros tres hombres de iglesia» ("Introducción» a su ed. del Lazarillo de Tormes, con un apéndice bibliográfico por Bienvenido C. Morros, 19. ${ }^{\mathrm{a}}$ ed. [1. ${ }^{\mathrm{a}} \mathrm{ed}$. 1987], Madrid, Cátedra [Letras Hispánicas, 44], 2006, p. 46). En referencia al prólogo de la obra, Fernando Lázaro-Carreter, lejos de advertir una falla entre las referencias librescas del prólogo y la autobiografía redactada por un humilde pregonero de vinos, repara sobre "una ambición [...] del protagonista, la de alcanzar honra literaria» (cf. "Construcción y sentido del Lazarillo de Tormes», Ábaco, I [1969], p. 45-134; recogido en Fernando Lázaro-Carreter, "Lazarillo de Tormes» en la picaresca, Barcelona, Ariel, 1972, p. 59-192; en particular, p. 173). Así podría ser, claro que con las precisiones apuntadas por F. Rico en su edición citada del Lazarillo de Tormes, p. 74-76. Sobre el estilo del Lazarillo, remitimos tan sólo al apartado «El estilo» de la "Introducción crítica» de Alberto Blecua a su ed. de La vida de Lazarillo de Tormes, 3. a ed. (1. a ed. 1982), Madrid, Castalia (Clásicos Castalia, 58), 1982, p. 38-44, con bibliografía en n. 66.

92. Cf. F. de Cascales, Tablas poéticas, ed. B. Brancaforte, p. 220.

93. No ha de perderse de vista, con todo, el característico empleo de un registro coloquial en el Guzmán, según puso de manifiesto George Peale, "Guzmán de Alfarache como discurso oral», Journal of Hispanic Philology, IV (1979), p. 25-57. 
del clero o la nobleza, sino que este propósito es solidario con la permanente recurrencia a "consejos sacados de las entrańas de la filosofía", de nuevo en palabras antes citadas de las Tablas poéticas. Según el soneto de fray Custodio Lobo editado en los preliminares de la segunda parte del Guzmán: «Esta ficción es una breve suma, / que, aunque entretenimiento nos parezca, / de morales consejos está llena» ${ }^{94}$.

Ya desde el prólogo a la primera parte del Guzmán, Mateo Alemán se ve forzado a justificar la inserción de digresiones moralizantes en el transcurso de su obra:

Y no es impropiedad ni fuera de propósito si en esta primera escribiere alguna dotrina; que antes parece muy llegado a razón darla un hombre de claro entendimiento, ayudado de letras y castigado del tiempo, aprovechándose del ocioso de la galera $[\ldots]^{95}$.

Son de señalar, en este punto, las críticas vertidas en la época hacia la mezcla de lo sagrado y lo profano, aunque tal vez nos apartemos de nuestros intereses ${ }^{96}$. En palabras de Giraldi, «Mescolare nelle cose divine el paganesimo con la cristianità è cosa fuori d'ogni decoro»" ${ }^{97}$, a lo que añade Riley el testimonio de Cervantes:

Cervantes, en el prólogo a la primera parte del Quijote, se refiere irónicamente a aquellos que guardan «un decoro tan ingenioso, que en un renglón han pintado un enamorado distraído y en otro hacen un sermoncico cristiano, que es un contento y un regalo oílle o leelle».

94. Cf. Mateo Alemán, Guzmán de Alfarache, I y II, ed. José María Micó, Madrid, Cátedra

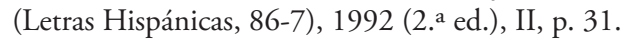

95. Ibid., I, p. 113. Sobre el valor de la digresión en Alemán, remitimos a Francisco Rico, «Estructuras y reflejos de estructuras en el Guzmán de Alfarache», Modern Language Notes, 82 (1967), p. 171-184; y La novela picaresca..., p. 61-98.

96. Como es claro, la mezcla de cuestiones profanas y cristianas afecta en principio al contenido, sin que repercuta necesariamente en las propiedades formales derivadas de la mezcla de los estilos. De hecho, los pastores de los villancicos tratan asuntos cristianos con sermo humilis; y un gran poema serio como Os Lusiadas mezcla deidades cristianas con las paganas.

97. Cf. Giambattista Giraldi-Cinthio, Discorso intorno al comporre dei romanzi, Venecia, 1554, p. 71. Es cita recogida en E. C. Riley, Cervantes's Theory..., p. 219. Se trata de un lugar común. Por recordar otro ejemplo, en el apartado "Sobre la elocución» de las Etimologías (lib. II, cap. XVI) de San Isidoro de Sevilla, leemos: «No debe mezclarse lo profano con lo religioso, lo desvergonzado con lo púdico, lo ligero con lo grave, lo frívolo con lo serio, lo ridículo con lo triste [...]» (ed. Oroz-Reta y Marcos-Casquero, vol. I, p. 379). 
Esta manera de escribir, añade luego, es un "género de mezcla de quien no se ha de vestir ningún cristiano entendimiento» ${ }^{98}$.

Nos encontramos, como estudió Cavillac, ante un problema de decoro en el que tal vez se cifre el nacimiento de una nueva épica en prosa. Según apunta el estudioso francés, quien revisó la poética de Alemán desde el punto de vista de los prologuistas, los "paratextos" alemanianos, la "philopoesía" del Pinciano y las opiniones literarias del escritor:

[...] esta definición totalizadora de la «épica en prosa» (afín a la naciente novela moderna) es precisamente la que se desprende de la opinión emitida por Valdés a propósito del Guzmán cuya mezcla de estilos pudo haber sido calificada por "cualquier terminista" (I, 125) de "criatura monstruosa». Y sobre el particular se recordará que Gracián, fino catador de la prosa alemaniana, no vacilaría en incluir la Atalaya, «aunque de sujeto humilde», en la estela de «las graves epopeyas» como «la Ulisiada de Homero»"

A la luz del Pinciano (a cuya Philosophía Antigua Poética remiten las siguientes referencias entre corchetes), Cavillac extrae importantes conclusiones:

98. Ibid., p. 219. Pese a todo, según estudió Riley, la postura de Cervantes en relación con las normas del decoro dista mucho de ser uniforme: «Los estrechos dogmas literarios del decoro y del estilo reflejan una visión del mundo, hoy ya anticuada, que se ordena según líneas jerárquicas. El Quijote nos da una perspectiva irónica desde la cual la antigua visión del mundo se combina con otra esencialmente moderna, en que coexisten los ideales exaltados y el más bajo materialismo como partes, distintas pero inseparables, de la experiencia humana» (ibid., p. 230); «la doctrina tradicional de los estilos [...] era observada por Cervantes sólo en algunos aspectos [...]. Realmente, la diferencia entre ambos [mundos] corresponde a la diferencia entre el Quijote y el Persiles, y no fue casual que en la primera de estas obras Cervantes alterara completamente las normas estilísticas y encontrara al mismo tiempo la relación más armónica que jamás consiguió entre lo poéticamente ideal y lo históricamente posible. En el Persiles, Cervantes deriva hacia lo poéticamente ideal, anulando el modo de relación que había establecido en su obra anterior» (p. 342-3). De acuerdo con planteamientos similares, J. González Maestro, "Poética clásica y preceptiva lopesca...», ha analizado las diferencias entre las primeras obras teatrales cervantinas (como El trato de Argel), según el crítico acordes a las exigencias tradicionales del decoro, y otras comedias como El gallardo español, con personajes como Nacor, «quien rompe completamente, movido por los celos, la cobardía y la traición, el decoro que se esperaría de alguien de su condición» (p. 71); El laberinto de amor, Pedro de Urdemalas, etc.

99. Cf. M. Cavillac, "Mateo Alemán y la "literatura", p. 381-409; en particular, p. 388-9. 
$\mathrm{Al}$ aglutinar en la esfera del poema épico [...] la comedia que «mira más a la económica, y la satírica, a la ética» [III, p. 237], junto con la tragedia (morata o patética) «que enseña política» [I, p. 218], Alemán abarcaba de hecho todas las experiencias útiles a "la vida humana». Esta apertura formal, forzosamente atalayista, a varios géneros hasta entonces jerarquizados, equivalía a dar cabida a «la persona común» o «mediana» (aquí, el "ciudadano») como medida de lo humano. Estimulado por la Philosophía Antigua Poética, el escritor sevillano consiguió dotar a su "poética historia» de un estatuto que, más allá del cuestionable concepto de «novela picaresca», sentaba las bases de la novela moderna ${ }^{100}$.

Al igual que en la obra de Alemán, en la continuación apócrifa del Guzmán de Alfarache (1602), el narrador se excusa repetidas veces por dar cabida a un discurso difícilmente esperable en boca de Guzmanillo. No faltan, con todo, algunos intentos puntuales de dignificación del pícaro mediante el acceso del personaje a las letras, con lo que se intenta conferir cierta verosimilitud a esta anómala situación narrativa:

[...] como en casa de monseńor casi por fuerza estudié latinidad y griego, y vi muchos libros, con mi buena memoria se me quedaron muchas especies de cosas de mil maneras; y, así, no te maravilles, amigo, que haga algunos discursillos y te dé cuenta de mis pensamientos, pues te podrían ser de provecho si los consideras; que para esto te cuento mi vida, para que escarmientes en cabeza ajena ${ }^{101}$.

Más adelante, el narrador afronta la extrañeza suscitada dentro del propio plano de la ficción por el «buen lenguaje retórico» de Guzmán, lo que trata de justificarse con los anteriores argumentos:

100. Ibid., p. 402 y las conclusiones recogidas en los tres últimos párrafos del estudio. Las opiniones del Pinciano sobre la mezcla de estilos han recibido la atención de José LaraGarrido, "Teoría y práctica de la épica culta en el Pinciano», Revista de Literatura, XLIV, 88 (1982), p. 5-56; Cécile Cavillac, «Alonso López Pinciano, philopoète», Poétique, 117 (1999), p. $95-121$.

101. Cf. Segunda parte de la vida del picaro Guzmán de Alfarache, ed. David MañeroLozano, Madrid, Cátedra (Letras Hispánicas, 609), 2007, p. 200. Según leemos en la primera parte del Guzmán alemaniano: «aprendí, en tiempo que allí estudié, razonablemente la lengua latina, un poco de griego y algo de hebreo» (cf. M. Alemán, Guzmán de Alfarache, ed. J. M. Micó, I, p. 456). En su segunda parte de la obra, M. Alemán matiza: «entonces no tenía otras [letras] que las de algunas lenguas que aprendí en casa del cardenal, mi señor, y aun ésas estaban en agraz, por mis verdes años» (cf. ed. J. M. Micó, II, p. 54-55). En n. 13, el editor destaca el contraste con la «exagerada e inverosímil erudición del falso Guzmán». 
Parecióme que convenía deshacer la violenta presumpción del vestido con prueba real y evidente, la cual puede más; y, así, enderezando mis razones en latín a mis clérigos, les dejé muy maravillados de que un mal trapillo sucio y ahumado supiese tan buen lenguaje retórico, que, a la verdad, como deprendí en aquella populosa ciudad de Roma, y de buen maestro, salí razonable dicípulo; demás que también supe mucho griego, que apura mucho y favorece la latinidad [...];

En Roma estudié gramática, griego y retórica; y, aunque no soy excelente como Démades ni Demóstenes [...] quizá tengo mejores interiores que exteriores y, debajo de mala capa, hay latinidad mal acreditada ${ }^{102}$.

Pese a estos esfuerzos de dignificación del pícaro, el narrador no puede sino reconocer en ocasiones la escasa credibilidad del personaje, a quien, según deducimos de algunos pasajes, se considera incapaz de superar su condición innoble:

¿Quién le hizo a Guzmán de Alfarache andar en estas consideraciones y hacerse consejero de estado? Ya te amonesté que saldría muchas veces de la historia de mi vida a los pensamientos que me ofrecían mis sucesos.

Quien oye esto luego me dirá: «¿Pues cómo, Guzmán, siendo vos tan predicador, no tomábades esos consejos? ¿De dónde habéis sacado tan buenas consideraciones y tan ruines hechos y propósitos?». Haz, hermano, lo que digo y no lo que hago ${ }^{103}$.

A decir verdad, la extrañeza provocada ante el enorme peso ideológico y la responsabilidad moral asignada a sujetos de tan ínfima extracción

102. Ibid., p. 313 y 314-315, respectivamente. El pasaje recuerda de cerca un episodio de El laberinto de amor de Cervantes, sobre el que se ha detenido J. González-Maestro, «Poética clásica y preceptiva lopesca...», p. 75: "El laberinto de amor es la comedia en la que Cervantes discute con mayor ironía y habilidad la autenticidad y el valor del principio del decoro. Tal es lo que consigue, por ejemplo, al presentar a Anastasio con una indumentaria propia de villano -duque en hábito de labrador- en el momento en que pronuncia ante Dagoberto uno de los mejores -y escasísimos- discursos en favor de la libertad humana contenidos en el teatro español del siglo XVII. Así, uno de los interlocutores le confirma "por Dios, que habéis hablado largamente, / y que, notando bien vuestro lenguaje, / es tanto del vestido diferente, / que uno muestra la lengua y otro el traje" (I, 214-217)».

103. Cf. Segunda parte de la vida del picaro..., ed. D. Mañero-Lozano, p. 437-438 y 199, respectivamente. 
social como Lázaro o Guzmán había originado ya en 1601 un curioso contraejemplo poético, en el que se reivindicaba el empleo de un «bajo estilo» ${ }^{104}$ acorde a la condición humilde del personaje protagonista. Nos referimos a La vida del picaro compuesta en gallardo estilo en tercia rima, obra en la que, de acuerdo con las declaraciones de su última estrofa, el tratamiento literario del "pícaro" refrenda de manera explícita las convenciones retóricas al uso: «De lodo os hablara quien es de lodo; I ninguno puede dar lo que no tiene; / humilde fue el sujeto, humilde el modo, / disculpa que a mis versos justa viene» ${ }^{105}$.

Por lo demás -adelantamos esta idea como hipótesis de trabajo-, la ruptura de la ratio personarum en el Lazarillo y los Guzmanes tal vez explique la dimensión paródica adoptada en una importante serie de obras compuestas entre 1604 y 1613, como la Primera parte del guitón Honofre (1604), de González; el Libro de entretenimiento de la picara Justina (1605), de F. López de Úbeda; la Historia de la vida del Buscón (posiblemente de 1605), de Quevedo; y la Novela y coloquio que pasó entre Cipión y Berganza (1613), de Cervantes.

El interés de esta cuestión, como es obvio, rebasa con mucho la atención que podemos dedicarle en estas páginas, en las que nos hemos conformado con intentar delimitar y contrastar los principales testimonios y problemas en torno a la formación y evolución de la «teoría de los estilos».

104. Cf. La vida del picaro compuesta en gallardo estilo en tercia rima [1601], ed. Adolfo Bonilla y San Martín, en Revue Hispanique, 9 (1902), p. 295-330; en particular, p. 304, v. 12.

105. Ibid., p. 321, vv. 332-5. 
